PROBLEMS

OF EDUCATION

IN THE $21^{\text {st }}$ CENTURY

Vol. 75 , No. 6, 2017

612

\title{
IMPLEMENTING THE COMPUTER-BASED NATIONAL EXAMINATION IN INDONESIAN SCHOOLS: THE CHALLENGES AND STRATEGIES
}

\author{
Heri Retnawati, Samsul Hadi, Ariadie C. Nugraha \\ Yogyakarta State University, Indonesia \\ E-mail: heri_retnawati@uny.ac.id, samsul_hd@uny.ac.id, ariadie@uny.ac.id
}

Janu Arlinwibowo

Muhammadiyah Health Sciences School of Kudus, Indonesia E-mail: januarlinwibowo@windowslive.com

Eny Sulistyaningsih, Hasan Djidu, Ezi Apino, Heni D. Iryanti Yogyakarta State University, Indonesia

E-mail: enylistya@gmail.com, hasandjidu@gmail.com, apino_ezi@gmail.com, heni.iryanti@gmail.com

\begin{abstract}
In line with technological development, the computer-based national examination (CBNE) has become an urgent matter as its implementation faces various challenges, especially in developing countries. Strategies in implementing CBNE are thus needed to face the challenges. The aim of this research was to analyse the challenges and strategies of Indonesian schools in implementing CBNE. This research was qualitative phenomenological in nature. The data were collected through a questionnaire and a focus group discussion. The research participants were teachers who were test supervisors and technicians at junior high schools and senior high schools (i.e. Level 1 and 2) and vocational high schools implementing CBNE in Yogyakarta, Indonesia. The data were analysed using the Bogdan and Biklen model. The results indicate that (1) in implementing $C B N E$, the schools should initially make efforts to provide the electronic equipment supporting it; (2) the implementation of CBNE is challenged by problems concerning the Internet and the electricity supply; (3) the test supervisors have to learn their duties by themselves and (4) the students are not yet familiar with the beneficial use of information technology. To deal with such challenges, the schools employed strategies by making efforts to provide the standard electronic equipment through collaboration with the students' parents and improving the curriculum content by adding information technology as a school subject.

Keywords: computer-based national examination, challenges in implementing CBNE, strategies for
\end{abstract} implementing $C B N E$.

\section{Introduction}

Each level of schools needs to conduct an evaluation in order to know the extent of the learning objective is attained. This evaluation is not only conducted by the school but also by the government. One of evaluation forms conducted by the Indonesian government is the national examination for students at the final year of each level of education. According to the Regulation of the Minister of Education and Culture of the Republic of Indonesia No.5 Year 2015, the national examination is the activity of nationally measuring and evaluating the attainment of passing competence in a certain school subject (Mendikbud, 2015). This national 
examination also has a role in sustaining the educational process as an important instrument for evaluating students' competence (Bichi \& Musa, 2015). Nitko and Brookhart (2011) state that the occurrence of an evaluation process is employed to obtain information to use to make a decision related to students, curriculum, learning programs, and educational policy. Therefore, the national examination as one of the evaluation forms in education has a very important role in education aspects around the world. Particularly in Indonesia, the national examination today no longer serves as the sole determining factor in student graduation, but rather, it serves to map the quality of the learning program and/or the school as stated in the Government Regulation of the Republic of Indonesia No.13 Year 2015. It is widely accepted that the results of the national examination can give a clear picture about the reality of education in Indonesia including the programs being run and other things related to educational systems. This educational mapping can help portray the condition of education in Indonesia in more detail and thus some followup actions can be further taken to improve it. This is in line with what has been explained by Bichi and Musa (2015) that evaluation in education is a process of collecting information of students' learning and performance to improve education, help measure students' competence in acquiring certain behaviour or specific knowledge of certain topics, and become the basis for ascertaining the quality of education at all levels.

However, the implementation of the previous national examination in Indonesia is inefficient and time-consuming. A lengthy process has been required to determine the results of the exam. Meanwhile, the development of this new era along with the development of technology today also have a significant impact on administering the national examination. The great demand for quick results has urged the need for technology utilization in it. The utilization of technology for the national examination in Indonesia can make the execution more effective, particularly in test distribution to schools in regions far from the city centre. The technological advancement for the national examination in Indonesia is then realized in the form of Computer-Based National Examination (CBNE) or also known as the national examination of Computer-Based Test (CBT) system. CBNE is a computer-based test whose item selection and presentation are administered in a computerized manner in which the test takers are given a different package of test items each (BSNP, 2015). In this test, students will no longer use a paper-based version, but rather, they completely use a computer-based system already programmed to get the results faster.

Indonesia began to administer the CBNE in the academic year of 2014/2015 (Mendikbud, 2015). It was only conducted by particular schools in some regions that fulfilled the predetermined criteria for administering CBNE. The schools administering CBNE at this initial stage are called CBNE-pilot schools. Today, more schools of junior high school (JHS) and senior high school (SHS) levels (Level 1 and 2) and vocational high schools (VHS) have already used the CBNE system. The limited number of schools administering CBNE is due to the reality that not all schools fulfil the predetermined requirements or criteria. According to the Agency of National Educational Standards (BSNP, 2015), the schools administering the national examination with a computer-based system have to previously submit a statement to confirm their willingness to participate as a test executor. The next step is checking by a verification team to make sure that the schools are well-equipped with facilities and resources needed.

Concerning technical requirements, schools administering CBNE are required to provide computers with the minimum specifications for both server and client computers (main and reserve), an Internet connection network with a minimum bandwidth of $1 \mathrm{Mbps}$ and a Local Area Network (LAN). The server computer (main and reserve) devices are PC/tower/desktop (not laptop); accessible port $80 ; 4$ core processor with a frequency of $1.6 \mathrm{GHz}$; the RAM is 8 $\mathrm{GB}$ at the minimum; the operating system (of 64 bytes) is Windows Server 8/Windows 7/Linux; there are two units of LAN CARD; the UPS (Uninterruptible Power Supply) which can last for 15 minutes; the number of server computers is according to the ratio of 1:40 (i.e., 1 server 
Heri RETNAWATI, Samsul HADI, Ariadie C. NUGRAHA, Janu ARLINWIBOWO, Eny SULISTYANINGSIH, Hasan DJIDU, Ezi APINO, Heni D. IRYANTI. Implementing the computer-based national examination in Indonesian schools: The challenges and strategies

PROBLEMS

OF EDUCATION

IN THE $21^{\text {st }}$ CENTURY Vol. 75, No. 6, 2017

614

computer is for 40 client computers, at the maximum); and there is at least one reserve server computer. Meanwhile, the main and reserve client computers should meet several requirements as follows: PCs or laptops with, at the minimum, monitors of $12 \mathrm{inch}$, processors of one core with a frequency of $1 \mathrm{GHz}$; a RAM of $512 \mathrm{MB}$; the operating system is, at the least, Windows $\mathrm{XP}$ installed as .NET Framework 3.5; the web browser is, at the minimum, Chrome with copied Exambro (the browser application from the educational evaluation centre for CBNE); the minimum number of client computers is according to the ratio of 1:3 (i.e., 1 client computer for 3 participants); the reserve client computers are at least 10\%; and headsets/earphones are provided (for the listening examination at senior high school). For the LAN hardware, the requirements are cables at least CAT5E 10/100/1000; each server with 1 switch and at least 24ports; a bandwidth of $1 \mathrm{Mbps}$ dedicated; the IP made static (the determination of the IP being made by the central executor); and at least 1 reserve unit. Besides, in general, UPS at least for server for 2 hours long and a generator set (or genset) for all the electronic equipment used in CBNE should be provided (Kemendikbud, 2017).

Schools that offer themselves to administer CBNE should fulfil the criteria not only related to computer facilities but also related to human resources. They should have at least one test supervisor, one technician, and room supervisors as needed who fulfil the criteria stated in the standard operational procedure (SOP) of the national examination. The criteria for test supervisors are as follows: they are teachers or educational personnel at a school who possess competence in information and communication technology; they have attended a relevant training or have served as a test supervisor in CBNE; they are willing to be assigned as test supervisors at schools administering CBNE; and they do not refuse to sign a pact of integrity. The criteria for technicians are as follows: they are teachers or educational personnel who have knowledge, skill, and experience in managing the school LAN; they have attended a relevant preparatory program or have served as a CBNE technician; and they are willing to sign a pact of integrity. Meanwhile, the criteria for supervisors are as follows: they are disciplined, honest, careful and responsible teachers who are able to keep something in confidentiality; they are in a healthy condition and able to supervise a national examination; they are not teachers of the subjects being supervised in the examination; they are not from the schools of CBNE participant; and they are willing to sign a pact of integrity (BSNP, 2017).

Although there is an increasingly greater number of schools that implement CBNE every year, the implementation still faces various problems. In general, the geographical condition of Indonesia becomes a crucial factor which can trigger those problems. As widely known, Indonesia consists of thousands of islands with diverse natural landscapes including the lowlands near the coast, the highlands and also large areas of hills stretching across regions in Indonesian. Indeed, the diversity of Indonesian geographical features can be a constraint in implementing CBNE. For example, there are some challenges in the provision of computers, internet connection and other facilities required for CBNE implementation. The weather condition that is occasionally unpredictable, such as heavy rain with thunder and lightning occurring in the daytime when CBNE is in progress, can disrupt or even damage the computer system and internet connection. As a developing country, Indonesia has not maximized technology utilization yet in many aspects of life. Internet connectivity is also a big challenge here because it is still unevenly distributed to all over regions in Indonesia, especially remote areas. Besides the constraints of internet access, the stability of electricity supply also becomes another challenge in administering CBNE (Sanni \& Muhammad, 2015). Similarly, the stability of the electricity in Indonesia is also limited, especially in remote regions. Another constraint of CBNE implementation in Indonesia is the social condition of its society. People in particular regions in Indonesia do not completely have awareness about the importance of education for their life, and thus, do not really care about matters supporting their children's education.

Regardless the various constraints faced in administering CBNE, there are some results of research comparing a paper-based national examination with a computer-based national examination. A study conducted by Retnawati (2015) indicates that a paper/pencil-based test 
and a computer-based test generally do not differ significantly in results and both of them do not influence the characteristics of the testing medium used. In addition, results of a study conducted by Piaw (2012) show that a computer-based national examination can be used to replace a paper-based national examination in testing at educational institutions. Similar findings are also given by Horchlehnert, Brass, Moeltner, \& Juenger (2011) through a study which reveals that a computer-based examination and a paper-based national examination for students of health sciences give the same result, by implication, a computer-based examination can be used as a good method to do written examination efficiently and fairly. Furthermore, a psychometric test using a computer-based model also gives the same result as that using the paper/pencilbased model (Baumer, Roded, \& Gafni, 2009). The advantages of computer-based testing are: it is efficient; it improves students' self-efficacy and motivation (Chua, 2012), and students have positive attitude toward CBT (Dammas, 2016).

\section{Research Aim}

Along with the development of this technological era, the various constraints in administering CBNE are expected to be well overcome and anticipated. It is because CBNE is necessary to be conducted even though its implementation still faces various challenges at the moment. The research concerned here was therefore particularly to analyse the challenges and strategies of Indonesian schools in the CBNE implementation.

\section{Researcher Role}

In this research, the researchers acted as observers during the CBNE implementation. They investigated the phenomena of challenges faced by schools and their strategies in implementing CBNE. By using a questionnaire and a focus group discussion, the researchers collected the data, recorded them in field notes and then analysed them. The researchers then made the conclusion based on their understanding of the existing phenomena.

\section{Methodology of Research}

\section{Type of the Research}

This research is qualitative phenomenological in nature. The type of this research is descriptive-exploratory research. The phenomenon described in this research was the challenges faced by JHSs, SHSs, and VHSs in implementing CBNE. The challenges in the CBNE implementation were examined from several points including the equipment, the human resources, the test takers (students), and the environment. This research also analysed the strategies used by the schools in implementing CBNE so that the examination could run smoothly.

\section{Time and Scope of Research}

This research was conducted from February to August 2017. It involved schools implementing CBNE in the Special Territory of Yogyakarta. There were two school levels both public and private schools including: (1) Junior High Schools (JHS) and (2) Senior High Schools (SHS) and Vocational High Schools (VHS). These schools were representative of schools located in urban and rural areas. 
Heri RETNAWATI, Samsul HADI, Ariadie C. NUGRAHA, Janu ARLINWIBOWO, Eny SULISTYANINGSIH, Hasan DJIDU, Ezi APINO, Heni D. IRYANTI. Implementing the computer-based national examination in Indonesian schools: The challenges and strategies

\author{
PROBLEMS \\ OF EDUCATION \\ IN THE $21^{\text {st }}$ CENTURY \\ Vol. 75, No. 6, 2017 \\ 616
}

\section{Data and Participants}

The data were collected by using a focus group discussion (FGD). The FGD was held one time. Before the FGD was held, the participants were required to fill in an open-ended questionnaire. This questionnaire included a number of items related to the sets of hardware (the server, the reserve server, and the client computers), the topology of a computer network, stability of the Internet connection, availability of electricity supply, the application setting (program installation, synchronization with the central system, and the running of Exambro), troubleshooting when administering CBNE, checking whether the students' answers had been already sent to the central server, the preparedness of the test supervisors, technicians, and the participants (students) of CBNE try-out and implementation, and the security for test equipment for several shifts of CBNE implementation. The questionnaire items were developed according to the requirements needed for the CBNE implementation synthesised from the theoretical review. The participants' responses to the questionnaire were then discussed in the FGD. Indepth interviews were also held when further clarification about the FGD data was needed.

Using the data obtained from the Educational Department of Yogyakarta about schools implementing the CBNE, 45 schools were invited to join the FGD. For each educational level, there were 15 schools including 10 public schools and 5 private schools located in urban and rural areas. There was one test supervisor and one technician for each school. Among 45 schools, there were 35 schools attending the FGD, consisting of 35 test supervisors (P1-P35) and 33 technicians (T1-T33) as the research participants of this study. They came from 11 JHSs, 12 SHSs, and 12 VHSs in Yogyakarta. The participants had at least one-year experience in implementing the CBNE at their schools (consisting of four series of activities, i.e. three simulations and one real CBNE implementation).

\section{Data Analysis}

The data obtained from the FGD were qualitative in nature consisting of various challenges and strategies in implementing the CBNE. The data were recorded in field notes and analysed through data reduction. The results were then presented in tables and re-examined to identify their subthemes. Afterwards, the data were analysed using a model developed by Bogdan \& Biklen (1982) to determine the inter-theme relations and gain more detail understanding. The results of this analysis were used to understand the phenomenon of challenges and strategies in implementing the CBNE in JHSs, SHSs and VHSs.

\section{Ethical Considerations}

The researcher informed the FGD participants of this research which was conducted to obtain their opinions about the CBNE implementation and strategies to overcome the challenges. This information can be used in other test locations. It can be also used to capture improved inputs, especially for educational policy makers in order to implement CBNE much better. To maintain the credibility of the data in this study, the name of the schools and the participants (test supervisors and technicians) involved in this study had been identified with pseudonyms, and all the data had been kept confidential as part of the research ethics procedures.

\section{Results of Research}

The implementation of CBNE at a number of schools in Indonesia still faces various constraints. However, the schools can use various strategies to overcome the constraints. The challenges and strategies are explained in detail as follows. 
Heri RETNAWATI, Samsul HADI, Ariadie C. NUGRAHA, Janu ARLINWIBOWO, Eny SULISTYANINGSIH, Hasan DJIDU, Ezi APINO, Heni D. IRYANTI. Implementing the computer-based national examination in Indonesian schools: The challenges and strategies

\section{Challenges of CBNE Implementation}

In 2017, all JHSs and VHSs in Yogyakarta had already implemented CBNE. To implement CBNE, the schools must have adequate facilities so that the computer-based examination system could run well. However, facts in the field indicated that many schools were faced with constraints in their efforts to fulfil the requirements of facilities which meet the minimum standards determined by the government. The mapping of challenges in facility requirements for CBNE implementation found in this research are presented in Table 1.

Table 1. Challenges in fulfilling facility requirements for CBNE.

\begin{tabular}{|c|c|c|}
\hline Challenges & Theme & Inter-Theme Relation \\
\hline The server computers are expensive. & \multirow{3}{*}{$\begin{array}{l}\text { Many schools do not yet have } \\
\text { ideal server computers as } \\
\text { recommended by BSNP. }\end{array}$} & \multirow{12}{*}{$\begin{array}{l}\text { The problems related to } \\
\text { the availability of comput- } \\
\text { ers which do not meet } \\
\text { the standards and limited } \\
\text { rooms influence the ratio } \\
\text { of server computers to } \\
\text { client computers, the } \\
\text { placement layout of } \\
\text { computers, and the cal- } \\
\text { culation of the electricity } \\
\text { power required. }\end{array}$} \\
\hline $\begin{array}{l}\text { Some schools do not have standard server computers } \\
\text { yet. }\end{array}$ & & \\
\hline The number of server computers is limited. & & \\
\hline $\begin{array}{l}\text { The computers in the school laboratory are already } \\
\text { old-fashioned. }\end{array}$ & \multirow{3}{*}{$\begin{array}{l}\text { The number and specification } \\
\text { of client computers become } \\
\text { constraints in administering } \\
\text { CBNE. }\end{array}$} & \\
\hline $\begin{array}{l}\text { The specifications of the client computers do not meet } \\
\text { the standards. }\end{array}$ & & \\
\hline The number of client computers is limited. & & \\
\hline The room area is limited. & \multirow{3}{*}{$\begin{array}{l}\text { Limited space influences the } \\
\text { ratio of the server computers } \\
\text { to the client computers and } \\
\text { the ideal computer layout. }\end{array}$} & \\
\hline $\begin{array}{l}\text { It is difficult to realize the ideal distance from one } \\
\text { computer to the other. }\end{array}$ & & \\
\hline $\begin{array}{l}\text { The computers in the school laboratory are perma- } \\
\text { nently positioned. }\end{array}$ & & \\
\hline A great quantity of electricity power is required. & \multirow{3}{*}{$\begin{array}{l}\text { Many schools are constrained } \\
\text { by electricity power and } \\
\text { stability. }\end{array}$} & \\
\hline $\begin{array}{l}\text { There is difficult access to electricity in particular } \\
\text { schools. }\end{array}$ & & \\
\hline There are rolling blackouts. & & \\
\hline
\end{tabular}

The availability of computers fulfilled the standards, sufficient rooms, and electricity become the main assets that should be possessed by the schools in implementing CBNE. However, the fact is that there are many constraints encountered by the schools in providing the aforementioned three components as required. The first constraint is the availability of computers. The school should provide computers as the server and client with the minimum specifications as follows: the server computer is a PC/tower/desktop in type (i.e., not a laptop) with a Xeon or i5 processor, a RAM of $8 \mathrm{~GB}$, a hard disk of $250 \mathrm{~GB}$, and a UPS while the client computer is a PC/laptop with a monitor of 12 inch in screen size, a dual core processor, and a RAM of $512 \mathrm{MB}$. Another requirement is that 1 server computer accommodates 40 client computers at most, there is at least one reserve server computer, one client computer could be used by 3 participants at most, and there are reserve client computers of at least $10 \%$ in quantity. Ideally, the need for server and client computers can be met by utilizing the computers already available in the laboratories at the schools. However, the fact is that the majority of schools do not have the computers with the specifications required and even if they have them, their number could not match the number of CBNE participants needing them. The cost of server and client computers is a heavy burden for the school because not only one computer unit is needed to serve as a client computer. Rather, the number of the client computer units should be equal with the number of the CBNE participants. Consequently, there are many schools which do not have computers with the minimum specifications and numbers required for administering CBNE. 
Heri RETNAWATI, Samsul HADI, Ariadie C. NUGRAHA, Janu ARLINWIBOWO, Eny SULISTYANINGSIH, Hasan DJIDU, Ezi APINO, Heni D. IRYANTI. Implementing the computer-based national examination in Indonesian schools: The challenges and strategies

PROBLEMS

OF EDUCATION

IN THE $21^{\text {st }}$ CENTURY Vol. 75, No. 6, 2017

618

The second constraint is the availability of rooms. In some cases, the schools do not have the building specifically provided for administering CBNE. Generally, the schools make use of a laboratory or a classroom, but this strategy raises some problems. The first problem is that the room area does not conform to the design for administering CBNE. This aspect is crucial because it is closely related to the ratio of the client computers to the server computers. The distance from one computer to the other is well arranged in order that participants cannot communicate and see one another's monitor screen (BSNP, 2017) or the distance is at least 1 meter (Kemdikbud, 2017). The limited server computer ownership makes the schools wish to be able to administer CBNE with a server-client computer ratio of 1:40 in order that the number of the server computers needed is as minimum as possible. However, having 1 server and 40 client computers in a room with the ideal distance from one computer to the other definitely requires a very spacious room. According to the test supervisors, the laboratory commonly used as the place for administering CBNE at schools could only accommodate 20 up to 36 client computers on average. The second problem is related to the placement layout of computers. In general, the schools make use of the computer laboratory to administer CBNE. Unfortunately, the computers in the laboratory at some schools are permanently installed in fixed positions and it is impossible to modify the layout. Therefore, the requirement for providing a classroom seating arrangement model with no seat facing each other as exhorted by Kemdikbud (2017) could not be realized at these schools.

The implementation of CBNE requires a good sufficient electric installation. Turning on very large numbers of electronic devices simultaneously requires a great stable electric power. Mostly the schools, which implement CBNE for the first time, attempt to upgrade their electricity power in order that all the electronic devices turn on effectively. If the client computers provided by the school use tube monitors, the electricity needed is extremely greater. Another problem with the electricity occurs at some schools located on the provincial borders because the access to electricity is relatively difficult. A very common trouble is a temporary shutdown of electric power (or rolling blackout). This problem is a major worry for the school. If such a blackout occurs when CBNE is being conducted, it will disrupt the process because all the equipment used is based on electronic devices with electricity supply from PLN.

Stability of Internet networks and understanding of Exambro software greatly determine whether CBNE runs smoothly. Table 2 presents the mapping of the challenges in the provision of Internet networks and Exambro software. CBNE requires a good and stable Internet connection. However, the fact is that even in Yogyakarta province, which is categorized as a signal-rich zone, there are still regions whose stability in Internet connection is not sufficiently conducive. According to a test supervisor, the Internet connection at his school tends to be slow so that it is not sufficiently conducive for administering CBNE. To improve the quality of the Internet connection, the school already makes efforts to propose the installation of networks based on optical fibres but until CBNE is held, it has not been yet realized. School location also influences the stability of the Internet connection. There are schools that are geographically located in a mountainous region which is lightning-prone so that there is a great risk of network damage to occur, as proven when the Internet connection was down during CBNE try out because the device for Internet connection was hit by lightning. 
Table 2. Challenges in providing internet networks and running the Exambro.

\begin{tabular}{|c|c|c|}
\hline Challenges & Theme & Inter-Theme Relation \\
\hline $\begin{array}{l}\text { The geographical location of the school is not suf- } \\
\text { ficiently conducive. }\end{array}$ & \multirow{2}{*}{$\begin{array}{l}\text { Many schools are constrained by } \\
\text { unstable Internet access. }\end{array}$} & \multirow{8}{*}{$\begin{array}{l}\text { The committee at } \\
\text { school should know } \\
\text { the potentials of the In- } \\
\text { ternet connection and } \\
\text { understand Exambro } \\
\text { well so that everything } \\
\text { could run smoothly }\end{array}$} \\
\hline The network at some schools is not stable. & & \\
\hline $\begin{array}{l}\text { The Exambro updating is too close to the day of } \\
\text { CBNE implementation. }\end{array}$ & \multirow{3}{*}{$\begin{array}{l}\text { The committee at school should } \\
\text { understand and make adjustments } \\
\text { in order that the software runs well. }\end{array}$} & \\
\hline Exambro cannot run compatibly with all browsers. & & \\
\hline Windows OS does not all give support. & & \\
\hline The central system is at times down. & \multirow{3}{*}{$\begin{array}{l}\text { There are constraints caused by the } \\
\text { central source. }\end{array}$} & \\
\hline $\begin{array}{l}\text { When listening tasks are to be done, no sound is } \\
\text { heard. }\end{array}$ & & \\
\hline Exambro could be minimized. & & \\
\hline
\end{tabular}

The constraints in operating the digital system in CBNE are divided in terms of two sources, namely, the school local system and the central system. The constraints whose source is the school local system are related to the OS (Operating System), the Exambro updating process, and the web browser. The OS is the house of all the applications in the computer. Using the newest OS version turns out to be not a guarantee of maximum performance of each computer unit in CBNE. Each OS type or version has its own character, especially in relation with specifications, in order to be able to run well. Some schools choose the OS Win10, which is the newest OS version. At a JHS, however, the installation of Win10 in server computers did not result in good collaboration with the CBNE system. The school decided to downgrade the OS server to Win7. With the older OS version, it turned out that the server computer could run well.

Exambro is the software used in administering CBNE. The software is updated in accordance with a request from the central server so that the local server gets the newest version. The problem that arises is that Exambro requires updating so often and its newest version usually releases very closely to the timing of CBNE implementation. At an SHS, for example, the Exambro updating was conducted closely to the day of CBNE implementation and this greatly disturbed the preparation. The test supervisors and technicians had to work overtime to complete the preparation and make sure that all the systems ran well with the newest Exambro version.

The last constraint coming from the school local system is the choice of web browser. As stated in the manual of CBNE implementation (Kemdikbud, 2017), Exambro would be optimum in performance if using the library application web browser 'Google Chrome.' However, in practice, many schools were often constrained in choosing the web browser. A test supervisor at a VHS stated that some schools had a problem concerning the web browser because the version of Google Chrome they installed is the newest one (i.e., too sophisticated). Choosing this newest Google Chrome version turned out to be useless as it did not to give a good impact and it rather became incompatible with the system (troublesome).

The next source of constraints came from the central system including the system performance, the set of examination items, and the working system of Exambro. These constraints could not be controlled by the local committee. It is true that the central system is the controller of all the systems running at the schools, but the implementation of CBNE, which is simultaneously conducted and involves so many participants, definitely raises the risk of disturbance in the central system. If the central system is down, the CBNE process will 
Heri RETNAWATI, Samsul HADI, Ariadie C. NUGRAHA, Janu ARLINWIBOWO, Eny SULISTYANINGSIH, Hasan DJIDU, Ezi APINO, Heni D. IRYANTI. Implementing the computer-based national examination in Indonesian schools: The challenges and strategies

PROBLEMS

OF EDUCATION

IN THE $21^{\text {st }}$ CENTURY Vol. 75, No. 6, 2017

620

be interrupted or even totally stopped. As a result, the implementation of CBNE did not run effectively as planned. In practice, various problems related to the central system occurred at the schools in administering CBNE. In an SHS for example, there was a day of CBNE implementation when the system was down due to problems from the central server. On the third day, the system was even offline, and therefore, the CBNE implementation was delayed by 65 minutes. Another SHS also faced a system trouble from the central server and consequently had to endure a 30-minute delay in administering CBNE. However, it is quite possible that at one school, those system constraints only partially occur.

The set of examination items is an absolute element that the local committee cannot control when any problem arises. All test items are managed by the central system and given to the local committee a few moments before CBNE is administered. A problem is found at an SHS when the listening section of English could not run as it should be. This constraint became worse as it only happened to six of the client computers in the room.

The last matter related to the performance of the system that the test supervisor and technician complain about is the Exambro software page appearance that could be minimized on the monitor screen. Such application ability to be minimized gives an impact that is not so good to the process of administering CBNE because it enables the students to simultaneously make use of another application in the computer. The case occurring most frequently is the utilization of the calculator-making application (which comes in a built-in condition with the computer) to aid the calculation process in answering a test item. According to the examination regulations, however, students are forbidden to use such a calculating aid.

Students' readiness in participating in CBNE is one of the aspects determining the smoothness in administering CBNE. However, the data indicate that there are still various notso-ideal students' conditions that make the administering of CBNE become hampered. The results of the mapping of CBNE constraints whose source is the student are as presented in Table 3.

The CBNE system makes differences sufficiently significant mainly because the process of doing the examination is under computer control. To be able to do the items well, students should first be familiar with the basic points of operating the computer, which is followed with understanding the related software and specifically the Exambro software. The students participating in CBNE vary in condition, there being those who are already IT literate and those who are still IT ignorant. Therefore, the school to administer CBNE arranges an introduction to CBNE by administering a try-out. However, data from technicians and test supervisors mention that students are not all competent yet at CBNE time. The main cause of the insufficient competence in IT is that not all students have the computer facility at home and not all students make use of the try-out well as means of introducing to them the system of the computer-based examination.

Table 3. Readiness of CBNE participants/students.

\begin{tabular}{|c|c|c|}
\hline Readiness of CBNE Participants/Students & Theme & $\begin{array}{l}\text { Inter-Theme } \\
\text { Relation }\end{array}$ \\
\hline $\begin{array}{l}\text { Students are not sufficiently skilled in utilizing the computer } \\
\text { for doing the examination when taking part in CBNE. }\end{array}$ & \multirow{2}{*}{$\begin{array}{l}\text { Students' mastery of information } \\
\text { technology and particularly of } \\
\text { Exambro is still insufficient. }\end{array}$} & \multirow{7}{*}{$\begin{array}{l}\text { Students are not } \\
\text { yet all able to } \\
\text { adjust them- } \\
\text { selves to CBNE } \\
\text { and students with } \\
\text { special needs } \\
\text { are still con- } \\
\text { strained in taking } \\
\text { part in CBNE. }\end{array}$} \\
\hline Students are surprised by the strict timer system in CBNE. & & \\
\hline $\begin{array}{l}\text { Students make pranks and fool around in making use of the } \\
\text { hardware. }\end{array}$ & \multirow{3}{*}{$\begin{array}{l}\text { Some students do not feel } \\
\text { sufficient responsibility for them- } \\
\text { selves and the CBNE hardware. }\end{array}$} & \\
\hline Students' motivation is insufficient. & & \\
\hline Students are not sufficiently disciplined. & & \\
\hline Many students are allergic to coldness. & \multirow{2}{*}{$\begin{array}{l}\text { There are constraints related to } \\
\text { health and special needs. }\end{array}$} & \\
\hline CBNE could not yet sufficiently facilitate the $d$ & & \\
\hline
\end{tabular}


Another problem related to students' readiness for the system concerns the time allocations of the examination. In the paper-and-pencil examination system used in the UN or other examinations, the time controller is the examination supervisor who is a teacher while the time control in CBNE is done by the computer system. The students are not yet familiar with the accurate time allocations because other examinations like final term examination or midterm examination are paper-and-pencil-based so that there is emotional interference from the supervisor often resulting in the occurrence of extra time. The students look surprised and unprepared when the time for working in the CBNE is ended by the system.

Students' sense of responsibility also becomes a focus of the spotlight from the school's authorities. Some cases indicate that often students do not feel sufficiently responsible for the CBNE equipment that they use and for themselves. Some schools complain about there being students making use of CBNE equipment not as they should; in fact, some test supervisors call it a prank or fooling around, which is intentionally amusing oneself by doing something else. The mouse and the headset are two computer accessories that students usually play with so that some of them are damaged. Such behaviour is considerably exhibited by students from another school which hitches a ride in taking the CBNE because their school does not have sufficient facilities. It is indicated that such behaviour appears because there is no sense of the objects as those belonging to them (i.e., the objects are not facilities belonging to their own school).

As for students' responsibility to themselves, many of them are still insufficiently motivated to do the CBNE. A test supervisor at an SHS reported the extreme case of some students coming to do the examination items for 15 minutes only. It was also seen that the discipline among them was not so good. The students didn't do the test seriously, as indicated by their time when they had done it.

Besides IT and responsibility, in the execution of CBNE, some students are constrained by the health factor. The CBNE is generally held in the laboratory with the air conditioner (AC) facility running and it makes students who are allergic to coldness become uncomfortable. In general, the reaction in the part of the allergic students is a blocked nose, a headache, a feeling of nausea, or a very severe cold feeling. With their body in such conditions, students are greatly hampered in their efforts to be able to do the examination items to the maximum.

The next thing concerns students' basic abilities. In 2017, CBNE still could not facilitate the disabled well. Some inclusive schools held a special paper-and-pencil-based national examination for their disabled students. The main reason concerned disabled students' preparedness because the schools were not yet able to get their disabled students ready for participation in CBNE and the disabled students themselves did not yet have sufficient selfconfidence to do computer-based examination items. For the students with disabled eyesight, there was another reason: in CBNE, items with pictures were not complemented with spoken description of the pictures so that sightless students could not get accurate access to them.

The final kind of constraint in administering CBNE is from the committee and supervisor sector. There are various situations that are not sufficiently ideal so that many complaints arise from test supervisors, and technicians. Results of the mapping done to the constraints encountered by test supervisors and technicians from the preparation until the execution of CBNE are as in Table 4.

PROBLEMS

OF EDUCATION

IN THE $21^{\text {st }}$ CENTURY

Vol. 75, No. 6, 2017

621 
Heri RETNAWATI, Samsul HADI, Ariadie C. NUGRAHA, Janu ARLINWIBOWO, Eny SULISTYANINGSIH, Hasan DJIDU, Ezi APINO, Heni D. IRYANTI. Implementing the computer-based national examination in Indonesian schools: The challenges and strategies

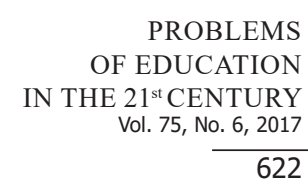

622

\section{Table 4. Constraints encountered by the CBNE committee and supervisors.}

\begin{tabular}{|c|c|c|}
\hline Constrains & Theme & Inter-Theme Relation \\
\hline $\begin{array}{l}\text { The number of teachers who were prepared to become } \\
\text { technicians and test supervisors is at a minimum. }\end{array}$ & \multirow{2}{*}{$\begin{array}{l}\text { There is a lack of human } \\
\text {-resources who are qualified } \\
\text { in IT. }\end{array}$} & \multirow{6}{*}{$\begin{array}{l}\text { The brevity of the prepara- } \\
\text { tion program and minimum } \\
\text { quantity of human resources } \\
\text { - who are qualified in IT make the } \\
\text { understanding of those on duty } \\
\text { of the system and execution of } \\
\text { CBNE insufficient. The problem } \\
\text { - is worsened with the addition } \\
\text { of the stamina being sapped } \\
\text { because CBNE is held in three } \\
\text { shifts. }\end{array}$} \\
\hline $\begin{array}{l}\text { The number of teachers who understand IT is at a mini- } \\
\text { mum. }\end{array}$ & & \\
\hline $\begin{array}{l}\text { The preparation given to test supervisors and technicians } \\
\text { is insufficient. }\end{array}$ & \multirow{3}{*}{$\begin{array}{l}\text { The preparation given to } \\
\text { technicians and test supervi- } \\
\text {-sors is not yet maximum. }\end{array}$} & \\
\hline $\begin{array}{l}\text { Test supervisors' and technicians' understanding is not yet } \\
\text { firm. }\end{array}$ & & \\
\hline The mastery of the CBNE SOP is insufficient. & & \\
\hline Many schools administer CBNE in 3 shifts. & $\begin{array}{l}\text { The test supervisors, and } \\
\text { technicians are exhausted. }\end{array}$ & \\
\hline
\end{tabular}

The initial constraint experienced by the school is the selection of the personnel to function as a technician and a test supervisor. These two positions demand sufficient IT insight in the individuals concerned in order that they could do their job well. Some schools admit having great difficulty in seeking the personnel with such competence; in fact, because there are no teachers and other school employees who are prepared to become technicians, a JHS is forced to recruit technicians from sources external to the school.

The constraints experienced by test supervisors and technicians are initiated with the admission that their understanding of CBNE is still not yet firm and often there are still doubts at times of being confronted with a case. Theoretically, such a situation ought not to occur because they have been given some briefing. However, according to their confession, the briefing received is still quite a minimum so that there are still many matters that they still could not thoroughly understand. Often, they encounter a problem that has not been mentioned at the time of the preparation and orientation program so that they could not respond to it as constraint speedily and accurately.

In administering CBNE, a constraint that often arises is difference in opinion between a test supervisor and a committee concerning task distribution. Basically, the tasks are already assigned in the SOP of the national examination, but it seems that some personnel do not thoroughly understand yet their respective tasks. In a case occurring at a VHS, the task of being responsible for the participants' presence list was passed to a test supervisor while it ought to be the responsibility of a committee member. Besides the problem of SOP mastery, committee members, technicians, and test supervisors also have difficulties in maintaining their stamina, especially at schools administering CBNE up to 3 shifts (with Session 1 from 07.30 a.m. to 09.30 a.m., Session 2 from 10.30 a.m. to 12.30 p.m., and Session 3 from 1.30 p.m. to 3.30 p.m.). The majority of the supervisors, technicians, and test supervisors complain about being exhausted when they are on the job in the last session.

\section{Solution Strategies}

Budget limitations are among the main causes of the school's difficulties in dealing with the various shortcomings of the facilities, especially in relation with matters concerning the availability of computers meeting prescribed standards and the electricity. For overcoming problems in the midst of budget limitations, the school takes various alternative steps in order that CBNE could keep running smoothly though without the support of ideal funding. Results of the mapping done for the strategies for overcoming the challenges resulting from the limitations of the school funding are presented in Table 5 . 
Table 5. Strategies for overcoming the challenges.

\begin{tabular}{|c|c|c|}
\hline Strategies & Theme & Inter-Theme Relation \\
\hline Using non-standard server & \multirow{3}{*}{$\begin{array}{l}\text { Some schools make use of available } \\
\text { computers as servers and do some } \\
\text { borrowing }\end{array}$} & \multirow{8}{*}{$\begin{array}{l}\text { Budget limitations force } \\
\text { the school to be smart in } \\
\text { making use of available } \\
\text { assets and maximize } \\
\text { their use via collaboration } \\
\text { through partnership }\end{array}$} \\
\hline $\begin{array}{l}\text { Modifying the computer so that it is appropriate } \\
\text { to become a server }\end{array}$ & & \\
\hline Borrowing server from students' parents & & \\
\hline Borrowing client computers & \multirow{3}{*}{$\begin{array}{l}\text { To provide client computers, the } \\
\text { school make them available, bor- } \\
\text { row them, and upgrade laboratory } \\
\text { computers }\end{array}$} & \\
\hline Upgrading laboratory computers & & \\
\hline Buying client computers & & \\
\hline $\begin{array}{l}\text { Arranging computer layout according to the } \\
\text { available room space }\end{array}$ & \multirow{2}{*}{$\begin{array}{l}\text { Adjusting computer layout to room } \\
\text { size and maximizing hardware use }\end{array}$} & \\
\hline Improving the quality of the connector cable & & \\
\hline
\end{tabular}

The price of local server computers for CBNE that is quite expensive is a problem for the school. Viewed from the point of their specifications, not all schools have computers with such requirements. Supplying them is the way most easily thought of to overcome the problem of server availability. However, not all schools have the financial ability to supply themselves with such computers by purchasing them. Such a situation demands a solution that takes the school's financial stability into consideration. Many schools make modifications on their available computers to make them fit for their new use. Some computers with specifications of a lower level are combined to produce a new one with specifications approaching those newly required and then it is perfected by means of supplying it with new hardware parts to make it meet the new standard of at least the minimum level. The schools admit that the strategy is sufficiently effective to provide servers with specifications at the minimum level of meeting the new needs at minimum cost. The second strategy is using a server with specifications lower in level than those of the minimum level recommended by the government. That strategy is used by some schools because they are already unable to find anymore possible source of funding. The decision to use a server with specifications below the standard set is surely highly risky for the smooth running of CBNE. Therefore, the school makes use of the try-out time to test server performance and it turns out that some schools using servers with processors of lower levels could administer CBNE smoothly. The third strategy is borrowing the server needed. However, in view of the relatively high level of the server specifications required, not all schools have access to such borrowing since very rarely are there people already having computers of such specifications and, moreover, the CBNE server should not be a laptop.

The Ministry of Education and Culture issues the decision that one client computer could be used by three students in the sense that CBNE could be held in three shifts per day. If the school has 270 students participating in CBNE, it should provide 100 client computers consisting of 90 core computers plus 10 reserve computers. The main problem concerning the availability of client computers is the availability in accordance with the number needed. In the majority, the schools admit that they are not yet able to meet that need independently. The first strategy used to meet the need is making the computers available by buying them. However, the very great number needed makes it impossible for the school to meet all the needs through the lane of purchases. The second strategy is modifying old computers until they are fit to be used as client computers. The system used to do it is generally cannibalism, namely, combining fitting components from various computers until they become one package fit to become a client computer. In addition, the system of upgrading the specifications of old computers is also used until they are fit to be client computers in CBNE. Some computers that are already old and with specifications under the standards set are identified and then the parts not yet 
Heri RETNAWATI, Samsul HADI, Ariadie C. NUGRAHA, Janu ARLINWIBOWO, Eny SULISTYANINGSIH, Hasan DJIDU, Ezi APINO, Heni D. IRYANTI. Implementing the computer-based national examination in Indonesian schools: The challenges and strategies

PROBLEMS

OF EDUCATION

IN THE $21^{\text {st }}$ CENTURY Vol. 75, No. 6, 2017

624

meeting the minimum standards set are upgraded. The third strategy is the final one because it is used only when one feels very much forced to do it. It is the strategy of borrowing a laptop or PC from various sources, especially teachers and other employees of the school. If the loans from teachers and other school employees still do not meet the need yet, the school generally collaborates with students' parents or guardians. In the majority, schools combine the three strategies to meet the needs.

Room availability is a problem which is relatively difficult to solve because it is not something that could be provided all of a sudden and its provision also takes very great expense. The absence of a special room for CBNE forces the school to make use of a classroom equipped with adequate electric supply, Internet access, and space area. Generally, the school takes the ICT laboratory as one chosen room because it has adequate Internet connection and electric power already with the addition of one or more other rooms with electric, Internet, and areal settings according to need. During CBNE, a constraint that could not be controlled to conform to the ideal condition is the inter-computer distance. The school tends to arrange the positional layout of a number of computers in accordance with room area though the ideal distance is 1 meter and the exhortation concerning computer positional layout that the computers do not face each other could not be complied with yet. The school puts aside the matter of distance and endeavours to catch up with the number of participants, considering that the CBNE items are already in random order when presented to each participant so that the possibility for participants to copy each other's work is relatively small. To maximize the usefulness of the available computer positional layout, generally the school makes efforts to use purchased connector cables of the best quality.

Electricity is the source of energy that should be well prepared in order that CBNE runs smoothly. Various constraints concerning the process of providing electric current is anticipated in various ways by the school. Table 6 presents the results of some mapping of the strategies in responding to constraints in supplying energy sources in administering CBNE.

The school endeavours to prepare the energy sources as well as possible in order that the CBNE process runs smoothly, making available client computers varying in power consumption like laptops, PCs with LCD/LED monitors, and PCs with tube monitors, which require considerable energy the most. To cope with the various needs of electricity, some electric circuit manipulation (or power distribution) is done so that each room could be supplied with electricity as needed.

Table 6. Strategies for supplying electricity at schools.

\begin{tabular}{lll}
\hline Strategies & Theme & $\begin{array}{l}\text { Inter-Theme Rela- } \\
\text { tion }\end{array}$ \\
\cline { 1 - 1 } Manipulating electric circuits & $\begin{array}{l}\text { Renewal and maintenance of electric } \\
\text { circuits and preparation of reserve } \\
\text { Collaborating with the State Electric Company }\end{array}$ & $\begin{array}{l}\text { Preparing, manag- } \\
\text { ing, and arranging } \\
\text { strategies for maxi- } \\
\text { mizing the electric } \\
\text { potential possessed }\end{array}$ \\
\cline { 1 - 2 } Provision of a generator set & $\begin{array}{l}\text { Being focused, effective, and ef- } \\
\text { ficient in using the electricity }\end{array}$ & \\
\hline Mocusing on the electric consumption for CBNE & & \\
\hline Minimizing the use of electronic equipment & &
\end{tabular}

A strategy to guarantee the electric supply needed is collaborating with the State Electric Company, especially concerning maintenance of electric circuits. In general, schools have a power quota that is more than enough for daily needs, but it would be disturbed when the use approaches the limits set. Some schools admit that the power quota for them ought to be able 
to start the electronic apparatus needed but in practice the electric power is always down when used to simultaneously start all the electronic devices. The main cause is the rare checking done to the performance of the circuits. In such cases, collaboration with the State Electric Company becomes crucial in the course of maximizing the electric potential in order to be able to calculate accurately the difference between the power quota and the amount of power needed so that if indeed the power supplied is not yet enough, then power raising is done. In some regions that are often subject to scheduled rotation of blackouts, the school makes efforts to conduct certain communication with the State Electric Company in order not to be subjected to scheduled blackout at the time of CBNE execution. In addition, to guarantee surety of energy source, the school provides itself with a genset.

Besides efforts of getting provided with energy sources, the school also makes economization of the electric consumption at CBNE time. All the electric power is focused on the room where CBNE is held. Various electronic apparatus outside the CBNE room with no need to be turned on are shut down. Hopefully, in that way there is no disturbance from the electric power being down due to the electricity being absorbed by electronic instruments outside the CBNE room. The next strategy is minimizing the electric consumption inside the CBNE room. Some schools turn off various electronic equipment not affecting the CBNE system, especially the $\mathrm{AC}$, in order that the electric consumption is at a minimum and the electric power does not become down.

CBNE is a digitally-based examination system that depends on the stability of the Internet connection and the performance of the application planted in each hardware. Facts in the field indicate that the school with its local committee should do extra work in order to be able to provide a stable network and assurance of smoothness in the running of all applications. Table 7 presents results of the mapping done for the strategies for providing the Internet connection and the participants' responses to the software-related constraints.

\section{Table 7. Strategies for providing the network and the participants' responses to} constraints related to the Exambro application.

\begin{tabular}{|c|c|c|}
\hline Strategies & Theme & Inter-Theme Relation \\
\hline Preparing the modem & \multirow{2}{*}{$\begin{array}{l}\text { Solution to network problems } \\
\text { depends on the school's ability } \\
\text { in funding. }\end{array}$} & \multirow{7}{*}{$\begin{array}{l}\text { Solution to network stability } \\
\text { constraints depends on } \\
\text { funding ability supported } \\
\text { with the work ethic, creativ- } \\
\text { ity, and maturity of those } \\
\text { on duty in responding to } \\
\text { problems during the execu- } \\
\text { tion of CBNE. }\end{array}$} \\
\hline Providing the tower & & \\
\hline $\begin{array}{l}\text { Installing the update using the administrative } \\
\text { remote }\end{array}$ & \multirow{5}{*}{$\begin{array}{l}\text { Constraints related to the } \\
\text { Exambro system are overcome } \\
\text { with the work ethos, creativity, } \\
\text { and maturity of the committee in } \\
\text { dealing with the constraints. }\end{array}$} & \\
\hline $\begin{array}{l}\text { Working overtime for the test supervisors and } \\
\text { technicians }\end{array}$ & & \\
\hline Exchanging computers during listening section & & \\
\hline Communicating with the test centre & & \\
\hline Managing students' psychical condition & & \\
\hline
\end{tabular}

PROBLEMS

OF EDUCATION

IN THE $21^{\text {st }}$ CENTURY

Vol. 75, No. 6, 2017

Generally, the school makes efforts to provide the network for Internet connection which is based on optical fibres because it is considered the most able to provide Internet connection with good stability. However, it is unfortunate that not all schools are already able to get an administrator of such a network. The next alternative for the school to take if not having any access to optical fiber network is providing itself with a tower. The reason is that the towerbased network is considered better and more stable in performance compared to a modem.

To assure network availability, the school generally provides itself with, at the minimum, two types of network. The majority of schools opt for the modem as stand-by companion of the main network already prepared. That step is taken to anticipate the occurrence of error in 
Heri RETNAWATI, Samsul HADI, Ariadie C. NUGRAHA, Janu ARLINWIBOWO, Eny SULISTYANINGSIH, Hasan DJIDU, Ezi APINO, Heni D. IRYANTI. Implementing the computer-based national examination in Indonesian schools: The challenges and strategies

\section{PROBLEMS \\ OF EDUCATION \\ IN THE $21^{\text {st }}$ CENTURY Vol. 75, No. 6, 2017 \\ 626}

the main network as in a case taking place at a vocational school located in a lightning-prone region. Prior to CBNE, the Internet connection network at the school dropped because it was hit by lightning and the network was damaged. In that situation, the modem became the solution to the problem of providing the Internet connection network.

One of the characteristics of a modem, compared to another network type, is its relatively insufficient sensitivity. Therefore, in the course of preparing a modem, the school should make some research on the match between the location and the cellular provider. The strength and stability of the signal from each provider vary greatly according to location. In fact, it is quite possible that inter-location difference of only around 5 meters could result in highly significant difference in Internet performance. An example of an extreme case took place at a vocational school which had to provide a modem with three different providers because each room had a compatibility with a different provider.

The next constraint is related to a condition which is not ideal in the Exambro software. The first complaint from the school concerns the software updating activity approaching the day of administering CBNE. Updating Exambro close to the day of administering CBNE is considered disturbing the preparations very much by the school local committee because the technicians and test supervisors have to prepare the computers all over again to fit the newest Exambro version. The majority of schools inform that, to face that matter, the school local committee have to work overtime to prepare the server and client computers one by one. However, some schools state that that is not a problem because they use remote admin to do the process of installing the newest software. The following are statements from the schools in relation with the Exambro renewal.

The next complaint is about an item-related error that could not be put under control by the school committee. A case of this occurred when 6 client computers in one of the rooms at an SHS could not present listening items as they should. The test supervisors responded to it by doing some manipulated moving of students' seats. The six students who could not do the listening items because of the error were asked to do the reading items first and, after finishing it, they were asked to exchange seating positions with six other students who had done the listening items. Though taking some moments, that solution was considered effective in overcoming the problem.

The time when the system does not run as it should makes the committee and the participants nervous. The first problem found at a JHS was the difficulty to log in. The committee hypothesized that the problem resulted from the crowded current due to simultaneous logging in. The problem was overcome when the committee instructed the CBNE participants to log in in turns based on seating position. The second problem concerned the system becoming offline as found at many schools. Generally, the committee recommends that students refresh the system by repeating the logging in. In some cases, the strategy runs well but in other cases caused by the central server having a problem, the strategy does not give any effect. Then it is demanded that the committee makes active communication with the central committee so that the real condition related to the constrained system could be identified well.

The national examination is a very great and important undertaking, particularly for the students. Therefore, the occurrence of constraints during the execution of CBNE could make them nervous. There is a demand that the test supervisors be able to manage the students' psychic state when encountering technical constraints in order that their mental state remains well protected so that they are able to do the examination items with smoothness. The school prepares the strategy of managing the students' psychic state at the time constraints occur during the briefing before administering CBNE.

The constraints faced by the students are important aspects that should be paid attention to in order that CBNE runs effectively. In this case, the schools employed various strategies to anticipate the challenges. An exposition of the strategies of minimizing the constraints originating in the students' condition during the execution of CBNE is presented in Table 8. 
Table 8. Strategies for anticipating CBNE constraints faced by the students.

\begin{tabular}{lll}
\hline Strategies & Theme & $\begin{array}{l}\text { Inter-Theme Rela- } \\
\text { tion }\end{array}$ \\
\hline Giving an orientation session & $\begin{array}{l}\text { Giving stricter orientation and } \\
\text { supervision to minimize the students' } \\
\text { Having stricter supervision }\end{array}$ & $\begin{array}{l}\text { Building a good } \\
\text { negative attitudes }\end{array}$ \\
\hline Allowing students to wear their alma mater coats & $\begin{array}{l}\text { Conditioning the room temperature } \\
\text { CBNE participants/ } \\
\text { setting the room temperature for comfort }\end{array}$ & $\begin{array}{l}\text { to create a conducive atmosphere } \\
\text { for the students }\end{array}$ \\
\hline
\end{tabular}

The school gives orientation to the students in order that they participate in CBNE as well as possible. The orientation emphasizes that the students are to be responsible for themselves and for the facilities in the CBNE room. The orientation is done continuously until a few minutes before starting to administer CBNE. The orientation is loaded with motivation by clearly outlining the functions of CBNE at the level of the students' personal self, the institution, up to the educational mapping mission. Therefore, hopefully, though the national examination is no longer the sole determinant of their graduation, they remain in possession of high motivation in participating in the national examination. In addition to motivation, the orientation also emphasizes using the computers and the accessories in the CBNE room as they should be used. A sense of the facilities used as their own is planted in students participating in CBNE at their own school and a sense of being responsible for the facilities used is planted in students who are visitors at the school where they participate in CBNE. A moment prior to the execution of CBNE, students are exhorted to be careful with various matters that could cause disturbance like a seated position with legs straightened or attractively posed so that it has the potential of damaging/shaking/severing a cable. In concord with the orientation strategy, during the execution of CBNE, stricter supervision is made. The strict supervision is done to anticipate various students who do not receive the orientation favourably so that their behaviour is still not sufficiently decent.

The next students' internal problem concerns the room temperature. Students' responses in relation with temperature vary greatly, there being students who like it cold with some others being allergic to coldness instead. The test supervisor attempts to adjust the temperature in accordance with comfort instead of wish. Efforts are made to enable all students to participate well in CBNE without being constrained by allergy. Some students who could not adjust themselves to the majority of students' comfort in the room are allowed to put on their jackets. The majority of schools urge that the jacket worn be the uniform coat of the students' alma mater so that students' neatness and uniformity are constantly maintained. The following are some statements by the school in relation with the strategy.

The constraints coming from the local committee are anticipated by forming a solid collaboration as a team. Reduced data of the various actions made by the local committee as efforts to neutralize constraints from the preparation until the execution of CBNE are presented in Table 9. 
Heri RETNAWATI, Samsul HADI, Ariadie C. NUGRAHA, Janu ARLINWIBOWO, Eny SULISTYANINGSIH, Hasan DJIDU, Ezi APINO, Heni D. IRYANTI. Implementing the computer-based national examination in Indonesian schools: The challenges and strategies

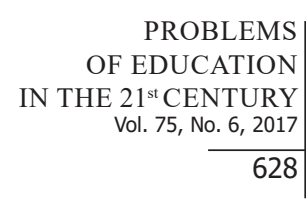

628

\section{Table 9. Strategies for dealing with constraints faced by the test supervisors and technicians.}

\begin{tabular}{|c|c|c|}
\hline Strategies & Theme & Inter-Theme Relation \\
\hline $\begin{array}{l}\text { Learning independently or via social media } \\
\text { group }\end{array}$ & \multirow{2}{*}{$\begin{array}{l}\text { Technicians and test supervisors carry } \\
\text { out an exploration independently }\end{array}$} & \multirow{6}{*}{$\begin{array}{l}\text { Technicians and test } \\
\text { supervisors must be } \\
\text { IT competent, in good } \\
\text { health, independent in } \\
\text { learning and they should } \\
\text { work together solidly in } \\
\text { a team. }\end{array}$} \\
\hline Using trial and error & & \\
\hline Choosing persons with IT knowledge & \multirow{2}{*}{$\begin{array}{l}\text { The personnel, particularly technicians, } \\
\text { should understand IT }\end{array}$} & \\
\hline Recruiting more outside technicians & & \\
\hline Choosing young personnel & \multirow{2}{*}{$\begin{array}{l}\text { Competent technicians and test supervi- } \\
\text { sors with good a stamina who are able } \\
\text { to work in a team should be intentionally } \\
\text { chosen }\end{array}$} & \\
\hline $\begin{array}{l}\text { Maintaining a good cooperation between the } \\
\text { test supervisor and the technician }\end{array}$ & & \\
\hline
\end{tabular}

Insufficient possession of knowledge is a hindrance initially felt by test supervisors and technicians. The briefing program is felt to be quite minimum in preparing them so that it could not yet meet the requirements for the knowledge needed by technicians and test supervisors in overcoming various problems. Technicians and test supervisors respond by learning independently or in groups after the briefing program. Independent learning is done by reading various literature and attempting to overcome problems by using the technique of trial and error. Group learning is done through discussions via social media. Thus, problems not overcome yet at the time of independent learning could be used as material for discussion in the social media group. Various problems are explored in the social media group by test supervisors and technicians.

In order to be able to understand the job fast, those chosen to be on duty should have superior IT knowledge. Thus, hopefully those on duty could make use of their already possessed IT knowledge as an asset in order to be more competent in responding to various situations. If the human resources at the school are not sufficient, the alternative is to recruit IT expert personnel from outside the school. Another matter related to personnel is that the school is well aware that the execution of CBNE would sap considerable energy because there are very many preparations like making sure that all equipment functions are well responding to instructions of conducting software update or to regulations from the central system, and coordinating with various parties so that the majority of schools choose those young in age and with good stamina to be the persons on duty to anticipate moments when they should do extra work and work overtime.

In the execution of CBNE, the persons on duty are to have their own respective jobs but in practice they are often overwhelmed by their tasks. Therefore, those on duty are directed to be flexible in playing their respective parts and assist each other in doing their job. The strategy employed by an SHS is that in the preparation for CBNE, all those on duty become technicians while at the time of CBNE all of them become test supervisors. All of them are responsible not only for their own respective jobs but also for the accomplishment of CBNE on the whole. The strategy is considered sufficiently effective in overcoming the great work load in a relatively short time.

\section{Limitations}

Although the Yogyakarta is a province in Indonesia which has characteristics of the region that represents Indonesia culturally and geographically, but in the reality, the regions in Indonesia are more varied. Some provinces consist of islands and mountains that lead to the increasingly complex challenges of CBNE implementation. Similarly, the ability of students in using information technology are also varied and these phenomena certainly affect the CBNE implementation. 


\section{Discussion}

Computer-Based National Examination (CBNE) is one of the evaluation forms done by the Indonesian government. It has been annually conducted in Indonesia since a few years ago and even the number of the schools implementing it has been continuously increasing. This CBNE is conducted to improve the quality of education in Indonesia. Bichi and Musa (2015: 290) support that the statement by saying that evaluation in education is a process of gathering information of students' learning and performance to improve education and to become the basis for ascertaining the quality of education at all levels. It is widely argued that CBNE is an effective mass evaluation means in education (Temitayo, Adebisi \& Alice, 2013) and that each student gets different examination items in CBNE (BSNP, 2015). Hence, CBNE is expected to improve the integrity of the national examination. However, it does not mean that the implementation of CBNE is already perfect and it does not have any constraint related to the equipment for administering it or the personnel involved in it. According to Thurlow, Lazarus, Albus, \& Hodgson (2010), besides its advantages, a computer-based test also has some drawbacks. A number of constraints that occur in the CBNE implementation, particularly in Yogyakarta, based on the results of FGD are constraints in providing the CBNE facilities including the provision of computers and sufficient rooms which meet the standards and stable supply of electricity; constraints in Internet networking (due to geographical location and limited network), and constraints in running Exambro; constraints in the CBNE participants' readiness; and constraints from the CBNE committee and supervisors. However, some of these constraints could be overcome or anticipated by the school personnel and other parties through some efforts. These challenges are in line with the results of studies conducted by Sanni \& Muhammad (2017) and Abubakar \& Adaebayo (2014).

The constraints in the CBNE implementation related to the provision of various facilities including the standard computers and rooms and stable supply of electricity are all very closely related with funding. It is also stated by Thurlow, Lazarus, Albus, \& Hodgson (2010) that in the CBNE implementation, some schools may not possess a sufficient number of computers and other supporting types of infrastructure. An alternative solution to deal with the constraint is that the schools should precisely utilize the available assets to minimize the lack of computers and rooms needed for implementing CBNE. In addition, cooperation with another school partner can be done by a particular school in the provision of computers or other equipment needed.

The next constraint is related to the instability of Internet connectivity in some regions where the schools implemented CBNE. This problem is not completely due to the fault or unpreparedness of the schools in implementing CBNE, but there are also other influencing factors such as the geographical location of the schools. The schools in urban areas could access the Internet easily while some other schools within rural areas had difficulty in getting stable Internet access. In fact, the Internet access has a very important role in the CBNE implementation to connect client computers with the central system such as in the process of delivering the students' answers. The constraint that might occur related to the Internet connectivity could be overcome by using a modem with various providers adjusted to the network stability at the school location and particularly in each room used for CBNE. In addition, for the schools which have the allocation of funds for the provision of Internet network could build a network tower to support the process of administering CBNE.

The process of running Exambro also becomes another constraint particularly for the technicians and the committee involved in administering CBNE who do not have sufficient experience with and knowledge of the Exambro software. The Exambro updating which usually releases very prior to the exam day is considered troublesome for some schools, especially for the administrator and committee. However, some other schools that have anticipated this constraint appear to be better prepared by making use of administrator remote to adjust the 
Heri RETNAWATI, Samsul HADI, Ariadie C. NUGRAHA, Janu ARLINWIBOWO, Eny SULISTYANINGSIH, Hasan DJIDU, Ezi APINO, Heni D. IRYANTI. Implementing the computer-based national examination in Indonesian schools: The challenges and strategies

PROBLEMS

OF EDUCATION

IN THE $21^{\text {st }}$ CENTURY Vol. 75 , No. 6, 2017

630 using the Exambro software can be anticipated by giving adequate preparation and training to the CBNE administrator and committee. Some orientation sessions to improve creativity and fast response in dealing with Exambro changing or updating also need to be given to them. In addition, the administrator, technicians and the committee of CBNE need to improve their work ethic and self-autonomy, for example, in learning from various sources about the CBNE implementation, particularly related to the software used for CBNE. This is very important because the role of the administrator or technician in the CBNE implementation is crucial from the beginning (in the preparation) until the end of the exam (such as performing the logout step if the students have finished their exam but forget to click the logout button on the computer, uploading all the students' answers to the central server, and other related tasks (Kemendikbud, 2017).

There are also constraints coming from the students. The student preparation in facing CBNE not only includes their cognitive aspects but also their psychological condition and their readiness related to the technical procedure in CBNE which are different from those in the previous paper-based national examinations. According to Ackerman and Barnett (2005), readiness is often interpreted as a skill, behaviour, and character of the child in relation with the expectation of the class or the school. Meanwhile, Sulistyaningsih and Sugiman (2016) state that students' readiness and anxiety have a negative correlation which means that the more the students are ready to face the national examination, the less anxious they become. Furthermore, the national examination has an impact on teachers and students' anxiety (Woolfolk \& Nicholich, 1984) and students' readiness and motivation (Astuti \& Retnawati, 2017). The teachers' anxiety is not only related to the students' competence and readiness in facing CBNE but also the exam process, especially in the schools where CBNE is implemented for the first time. Therefore, both the teachers and the students need to be given adequate preparation and training to face CBNE. As stated by Thurlow, Lazarus, Albus, \& Hodgson (2010), in implementing a computer-based test, a considerable amount of time is needed for conducting a training for the students about the technical procedures of the CBNE system, particularly for those who have no skill in using a computer. It is also possible that some students experience anxiety when using a computer in their exam (Thurlow, Lazarus, Albus, \& Hodgson (2010). The students' anxiety can impede their concentration (Mayer, 2008; Vitasari, Wahab, Othman, \& Awang, 2010) and this condition will negatively affect their ability in completing CBNE. The school and the student parents in this case have an important role in preparing their mental condition and skills in using a computer. However, today there is no longer information and communication technology (ICT) subject at JHS and SHS levels. In Curriculum 2013, information and communication technology (ICT) is omitted from the list of school subjects taught to students. Indeed, this makes students less familiar with and capable of using a computer, particularly those studying at remote schools.

The impact is that many students still have difficulties in using basic parts of computer hardware such as keyboards and headsets. The students' low ability in using keyboards causes them to feel more comfortable and well prepared with the paper-based examination than the computer-based examination (Al-Amri, 2007). In fact, the presence of ICT as a school subject indirectly gives assurance of better facilities and infrastructures from the government such as the availability of electricity power and computer laboratory at each school. The ICT subject can also become the basis for computer use for students, especially those attending remote schools. While the government is currently developing the implementation of CBNE, many students in some remote schools are not computer literate. By implication, school officials or teachers should work very hard to give their students guidance in using a computer as needed for the CBNE implementation. It is expected that the removal of ICT subject from JHS and SHS levels will be substituted with the integration of computer use in all school subjects. However, not all teachers master computer use. Many teachers also scarcely use a computer in their teaching 
and learning process. Therefore, this ICT integration will also face some constraints which then impede the students' readiness for participating in CBNE. As widely argued, respondents' unfamiliarity in using technology is one of obstacles in implementing the computer-based examination (Retnawati, 2015; Rezaie \& Golshen, 2015; Magdin \& Turčáni, 2015).

Another constraint in administering $\mathrm{CBNE}$ is related to the $\mathrm{CBNE}$ committee and supervisors. The committee and supervisors in administering CBNE should meet various requirements predetermined by the government. Not only the committee in administering CBNE is responsible for the process of administering CBNE but also, they should know what action would be taken if a problem arises when administering CBNE. Therefore, the committee also generally need training first as a step in preparation to administering the computer-based test (Thurlow, Lazarus, Albus, \& Hodgson, 2010), just like the technicians (as technological staff members). Other than that, the supervisors should also know what actions to do and how to do them as CBNE supervisors.

\section{Conclusions}

This research concludes that various constraints still occur in the implementation of CBNE in Indonesia. These constraints include problems in providing facilities such as the stable electric current, computers and rooms which meet the test standard/requirement; Internet network problems; the preparedness of CBNE participants in using the computer; and constraints related to the committee and supervisors. However, such constraints can be anticipated and overcome by means of several activities such as preparing, managing, and arranging strategies in maximizing the use of available facilities and resources at the school (for example, computers, servers, electricity, and networks); arranging the layout number of computers according to the room space available; anticipating and preparing students' mental condition in facing the CBNE; making a solid collaboration between technicians and test supervisors; and giving training and briefing sessions before administering the CBNE.

Considering the constraints in implementing the CBNE, some suggestions are made to deal with the challenges. First, there should be initiatives from the teachers to meet the standards of the equipment used to administer the CBNE. Second, the government should improve a more even distribution of facilities for implementing the CBNE such as electric power, networks, and computer sets to regions all over Indonesia. Third, ICT should be integrated in the curriculum as a school subject at the JHS and SHS levels to help the students prepare for the CBNE. Fourth, the students' parents together with the society should be actively engaged in supporting the CBNE implementation. At last, schools in other countries which want to implement the CBNE need to understand the challenges and readiness of its components. This is to ensure that the schools can develop an appropriate strategy in order the CBNE implementation can run effectively and yield a good result without showing any bias.

\section{References}

Abubakar, A. S., \& Adebayo, F. O. (2014). Using computer based test method for the conduct of examination in Nigeria: Prospects, challenges and strategies. Mediterranean Journal of Social Sciences, 5 (2), 47-55. doi:10.5901/mjss.2014.v5n2p47.

Ackerman, D. J., \& Barnett, S. (2005). Prepared for kindergarten: What does "readiness" mean? New Brunswick, NJ: National Institute for Early Education Research.

Alabi, A. T., \& Issa, A. O. (2012). The use of computer based testing method for the conduct of examinations at the University of Ilorin. International Journal of Learning \& Development, 2 (3), 68-80. doi:10.5296/ijld.v2i3.1775.

Al-Amri, S. (2007). Computer-based vs. paper-based testing: Does the test administration mode matter? Proceedings of the BAAL Conference 2007, 101-110. Retrieved from https://pdfs.semanticscholar.org/86df/c22d8a8b5ff19325b6c991ab37e43ab9801d.pdf? $\mathrm{ga}=2.189936171 .1611720179 .1507555294-1854837378.1507555294$.

PROBLEMS

OF EDUCATION

IN THE $21^{\text {st }}$ CENTURY

Vol. 75, No. 6, 2017 
Heri RETNAWATI, Samsul HADI, Ariadie C. NUGRAHA, Janu ARLINWIBOWO, Eny SULISTYANINGSIH, Hasan DJIDU, Ezi APINO, Heni D. IRYANTI. Implementing the computer-based national examination in Indonesian schools: The challenges and strategies

\section{PROBLEMS \\ OF EDUCATION \\ IN THE $21^{\text {st }}$ CENTURY Vol. 75, No. 6, 2017 \\ 632}

Astuti, F. S., \& Retnawati, H. (2017). The effect of national examination's policy on readiness, motivation, school test score, and national examination score. The Online Journal of New Horizons in Education, 7 (3), 58-66. Retrieved from http://tojned.net/journals/tojned/articles/v07i03/v07i0307.pdf.

Baumer, M., Roded, K., \& Gafni, N. (2009). Assessing the equivalence of internet-based vs. paper-andpencil psychometric test. Proceedings of the 2009 GMAC Conferencerence on Computerized Adaptive Testing. Retrieved from www.psych.umn.edu/psylabs/CATCentral/psylabs.

Bichi, A. A., \& Musa, A. (2015). Assessing the correlation between continuous assessment and examination scores of education courses. American International Journal of Research in Humanities, Arts and Social Sciences, 10 (3), 290-294. Retrieved from http://iasir.net/AIJRHASSpapers/ AIJRHASS15-391.pdf.

Bogdan, R. C., \& Biklen, S. K. (1982). Qualitative research for education: An introduction to theory and methods. Boston, MA: Allyn and Bacon.

BSNP. (2015). Peraturan Badan Standar Nasional Pendidikan No. 0034/P/BSNP/XII/2015 tentang prosedur operasional penyelenggaraan ujian nasional tahun pelajaran 2015/2016. [BSNP. (2015). Regulation of Agency of National Educational Standards No. 0034/P/BSNP/XII/2015 about operational procedure of administering national examination in 2015/2016]. (Idn).

BSNP. (2017). Peraturan badan standar nasional pendidikan No. 0043/P/BSNP/I/2017 tentang prosedur operasional penyelenggaraan ujian nasional tahun pelajaran 2016/2017. [BSNP. (2017). Regulation of Agency of National Educational Standards No. 0043/P/BSNP/I/2017 about operational procedure of administering national examination in 2016/2017]. (Idn).

BSNP. (2017). Prosedur Operasional Standar Penyelenggaraan Ujian Nasional. Jakarta: BNSP. [BSNP. (2017). Standards operational procedure of administering national examination]. (Idn).

Chua, Y. P. (2012). Effects of computer-based testing on test performance and testing motivation. Computers in Human Behavior, 28 (5), 1580-1586. doi: 10.1016/j.chb.2012.03.020.

Dammas, A. H. (2016). Investigate students' attitudes towards computer based test (CBT) at chemistry course. Archives of Business Research, 4 (6), 58-71. doi: 10.14738/abr.46.2325.

Horchlehnert, A., Brass, K., Moeltner, A., \& Juenger, J. (2011). Does medical students' preference of test format (computer-based vs. paper-based) have an influence on performance? Journal of Medical Education, 11 (89), 1 - 6. doi: https://doi.org/10.1186/1472-6920-11-89.

Kemendikbud. (2017). Manual Ujian Nasional Berbasis Komputer 2017. Jakarta: Puspendik. [Kemendikbud. (2017). Manual of computer-based national examination 2017. Jakarta: Puspendik].

Magdin, M., \& Turčáni, M. (2015). A few observations and remarks on time effectiveness of interactive electronic testing. Informatics in Education, 14 (1), 83-102. doi: http://dx.doi.org/10.15388/ infedu.2015.06.

Mayer, D. P. (2008). Overcoming school anxiety: How to help your child deal with separation, tests, homework, bullies, math phobia, and other worries. New York, NY: Amacom.

Mendikbud. (2015). Peraturan Menteri Pendidikan dan Kebudayaan Republik Indonesia No. 5 tahun 2015 tentang kriteria kelulusan peserta didik, penyelenggaraan ujian nasional, dan penyelenggaraan ujian sekolah/madrasah/pendidikan kesetaraan pada SMP/MTS atau yang sederajat dan SMA/ MA/SMK atau yang sederajat. [Mendikbud. (2015). Regulation of the Minister of Education and Culture of Republic of Indonesia No. 5 Year 2015 about the students' criteria to pass national examination in junior high school]. (Idn).

Nitko, A. J., \& Brookhart, S. M. (2011). Educational assessment of student (6 ${ }^{\text {th }}$ ed.). Boston, MA: Pearson.

Piaw, C. Y. (2012). Replacing paper-based testing with computer-based testing in assessment: Are we doing wrong? Procedia - Social and Behavioral Sciences, 64 (2012), 655-664. doi: 10.1016/j. sbspro.2012.11.077.

Retnawati, H. (2015). The comparison of accuracy scores on the paper and pencil testing vs. computer based testing. The Turkish Online Journal of Educational Technology, 14 (4), 135-142. Retrieved from http://www.tojet.net/articles/v14i4/14413.pdf.

Rezaie, M., \& Golshan, M. (2015). Computer adaptive test (CAT): Advantages and limitations. International Journal of Educational Investigations, 2 (5), 128-137. Retrieved from http://www. ijeionline.com/attachments/article/42/IJEI_Vol.2_No.5_2015-5-11.pdf.

Sanni, A. A., \& Mohammad, M. F., (2015). Computer based testing (CBT): An assessment of student perception of JAMB UTME in Nigeria. Computing, Information Systems, Development Informatics \& Allied Research Journal, 6 (2), 13-28. Retrieved from https://pdfs.semanticscholar.org/8a4c/86f 053248651f3bbc55ac66b0b98c6e94f6f.pdf. 
Heri RETNAWATI, Samsul HADI, Ariadie C. NUGRAHA, Janu ARLINWIBOWO, Eny SULISTYANINGSIH, Hasan DJIDU, Ezi APINO, Heni D. IRYANTI. Implementing the computer-based national examination in Indonesian schools: The challenges and strategies

Sulistyaningsih, E., \& Sugiman, S. (2016). The effect of CBT national examination policy in terms of senior high school students' cognitive readiness and anxiety facing mathematics tests in DIY Province. Jurnal Riset Pendidikan Matematika, 3 (2), 198-208. doi: http://dx.doi.org/10.21831/ jrpm.v3i2.10868.

Temitayo, F., Adebisi, A., \& Alice, O. (2013). Computer-based test (CBT) system for university academic enterprise examination. International Journal of Scientific \& Technology Research, 2 (8), 336342. Retrieved from http://www.ijstr.org/final-print/aug2013/Computer-based-Test-Cbt-SystemFor-University-Academic-Enterprise-Examination.pdf.

Thurlow, M., Lazarus, S. S., Albus, D., \& Hodgson, J. (2010). Computer-based testing: Practices and considerations (Synthesis report 78). Minneapolis, MN.: University of Minnesota, National Center on Educational Outcomes.

Vitasari, P., Wahab, M. N. A., Othman, A., \& Awang, M. G. (2010). A research for identifying study anxiety sources among university students. Journal of International Education Studies, 3 (2), 189196. Retrieved from http://files.eric.ed.gov/fulltext/EJ1066077.pdf.

Woolfolk, A. E., \& Nicholich, L. M. (1984). Educational psychology for teachers ( $2^{\text {nd }}$ ed.). Englewood Cliffs, NJ: Prentice Hall.

Received: November 10, 2017

Accepted: December 20, 2017

\begin{tabular}{|c|c|}
\hline Heri Retnawati & $\begin{array}{l}\text { Dr, Associate Professor, Mathematics Department, Mathematics and Science } \\
\text { Faculty, Yogyakarta State University, Indonesia, Jl. Kolombo Karangmalang } \\
\text { Yogyakarta } 55281 \text { Indonesia. } \\
\text { E-mail: heri_retnawati@uny.ac.id }\end{array}$ \\
\hline Samsul Hadi & $\begin{array}{l}\text { Associate Professor, Department of Electrical Engineering Education, } \\
\text { Engineering Faculty, Yogyakarta State University, Indonesia, Jl. Kolombo } \\
\text { Karangmalang Yogyakarta } 55281 \text { Indonesia. } \\
\text { E-mail: samsul_hd@uny.ac.id }\end{array}$ \\
\hline Ariadie C. Nugraha & $\begin{array}{l}\text { Assistant Professor, Department of Electrical Engineering Education, } \\
\text { Engineering Faculty, Yogyakarta State University, Indonesia, Jl. Kolombo } \\
\text { Karangmalang Yogyakarta } 55281 \text { Indonesia. } \\
\text { E-mail: ariadie@uny.ac.id }\end{array}$ \\
\hline Janu Arlinwibowo & $\begin{array}{l}\text { M.Pd., Lecturer and Researcher, Muhammadiyah Health Sciences School } \\
\text { of Kudus, Indonesia, Jl. Ganesha I, Purwosari, Kudus, Central Java } 59316 \\
\text { Indonesia. } \\
\text { E-mail: januarlinwibowo@ windowslive.com }\end{array}$ \\
\hline Eny Sulistyaningsish & $\begin{array}{l}\text { M.Pd., Alumnae, Master Program in Mathematics Education, Graduate } \\
\text { School of Yogyakarta State University, Jl. Kolombo Karangmalang Yogyakarta } \\
55281 \text { Indonesia. } \\
\text { E-mail: enylistya@gmail.com }\end{array}$ \\
\hline Hasan Djidu & $\begin{array}{l}\text { M.Pd., Alumnae, Master Program in Mathematics Education, Graduate } \\
\text { School of Yogyakarta State University, Jl. Kolombo Karangmalang Yogyakarta } \\
55281 \text { Indonesia. } \\
\text { E-mail: hasandjidu@gmail.com }\end{array}$ \\
\hline Ezi Apino & $\begin{array}{l}\text { M.Pd., Alumnae, Master Program in Mathematics Education, Graduate } \\
\text { School of Yogyakarta State University, Jl. Kolombo Karangmalang Yogyakarta } \\
55281 \text { Indonesia. } \\
\text { E-mail: apinoezi@gmail.com }\end{array}$ \\
\hline Heni D. Iryanti & $\begin{array}{l}\text { M.Pd., Alumnae, Master Program in English Education, Graduate School of } \\
\text { Yogyakarta State University, Jl. Kolombo Karangmalang Yogyakarta } 55281 \\
\text { Indonesia. } \\
\text { E-mail: heni.iryanti@gmail.com }\end{array}$ \\
\hline
\end{tabular}

PROBLEMS

OF EDUCATION

IN THE $21^{\text {st }}$ CENTURY

Vol. 75, No. 6, 2017 